\title{
Frailties of the Flesh: Observing the Body in Chimamanda Ngozi Adichie's Purple Hibiscus
}

\author{
CORINNE SANDWITH \\ University of Kwazulu-Natal \\ corinne.sandwith@up.ac.za
}

\begin{abstract}
In this article, I offer a reading of Chimamanda Ngozi Adichie's Purple Hibiscus (2003) through the lens of the body. References to the body in Purple Hibiscus are frequent, even excessive. In its insistent emphasis on the body, I suggest, the novel establishes affiliations with an emergent tradition of African writing in which various forms of "body writing" are deployed as part of a destabilizing aesthetic. These aesthetico-political concerns are developed in a number of ways-in the inscriptions of the body as a site of physical and discursive violence, in the positive reimagining of the black body against a history of shame, and in the novel's refracted critique of the postcolonial potentate whose body becomes the object of a destabilizing and satirical gaze. By means of the trope of the bodily grotesque-along with a repeated gesture of ironic unmasking - the novel asserts the reciprocal connections between the private violence of the domestic sphere and the public violence of the postcolonial state. Also important is a pervasive structure of reciprocity or mirroring in which several unexpected connections between conventionally bounded conditions are disclosed. Not least of these, I suggest, are the links between Western enlightenment-democracy and the violence of the postcolonial state.
\end{abstract}

$P$ urple Hibiscus (2003) begins with a family crisis, an event to which the narrative returns at intervals. The crisis occurs on Palm Sunday when Jaja, eldest son of the Achike family, refuses to participate in the Catholic ritual of Holy Communion. To this, his father, Eugene, responds by throwing his missal and breaking a collection of cherished porcelain figurines displayed in a glass case. Jaja gives two reasons for his transgression, both of which make a 
provocative reference to the body. The first, deliberately flippant, is that "the wafer gives me bad breath" (6). With the substitution of the word "wafer" for "host," Jaja undermines one of the central aspects of the liturgical rite, the transformation of the wafer into the body of Christ. With these words, "the body of our Lord" is stripped of its consecrated status, rematerialized and made mundane. In resisting the notion of religious transcendence, Jaja's comments bring the spiritual back to earth. As a reference to Eugene's wafer-making factories, part of a vast commercial enterprise and the source of his spectacular wealth, the word "wafer" also effects an untoward intrusion of the secular, profit-making world into the sanctified spaces of the church. The second reason Jaja offers for his rebellion is that "the priest keeps touching my mouth and it nauseates me" (6). In this second remark, Jaja draws unseemly attention to the priest's human body and introduces the suggestion of libidinal desire. In this striking opening movement, the body of Christ becomes both an ordinary material object and a sign of neocolonial commerce; in similar fashion, the transcendent figure of the priest is made flesh. Both actions foreground or isolate a gesture of transgressive unmasking - the emperor divested of his clothes.

The opening chapter provides just one instance of the novel's persistent corporeal emphasis and points to the unsettling function of the body and body figuring in the text as a whole. The importance of the body narrative is underscored not only by graphic descriptions of intimate physical violence, but also by the particular focus provided by the first-person narrative voice, a focalizing perspective that gives insistent, uneasy, and concentrated attention to the attitudes and attributes of the human form. In this article I pursue the logic of this narrative gaze, giving attention to the various inscriptions of the body and embodiment in the text and exploring their significance in relation to the novel's overall concerns. Central to this analysis is the novel's deployment of the bodily grotesque, both as a means of exploring the spectacle of autocratic power and of effecting its satirical unmasking: in a characteristic textual gesture, I argue, the fetish that aspires to omnipotence is repeatedly brought low. The trope of the body is also significant for the connections it articulates between patriarchal tyranny in the private sphere and the practices and styles of public autocratic rule in the Nigerian postcolony. Similar gestures of transgressive unmasking are evident in what is identified as a pervasive narrative structure of reciprocity, refraction, and mirroring. This, along with a marked tendency in the novel toward textual excess, becomes a means of disclosing hitherto unacknowledged or disavowed connections between conventionally polarized states.

My reading of the body in Purple Hibiscus is placed in relation to an established corpus of work on the body as a powerful political and cultural signifier, including, among others, Frantz Fanon's analysis of the racialized colonial body, Michel Foucault's notion of body discipline, Mikhail Bakhtin's reading of the bodily grotesque, Elizabeth Grosz's feminist reading of the gendered body, and Achille Mbembe's reflections on the body of the postcolonial potentate. Of additional significance is a growing body of literature on African cultural production that has given attention to the subject of the body and the possibilities of "body writing" and "body voicing" for a transgressive or destabilizing aesthetic. ${ }^{1}$ As suggested above, the attention I give to the body in Purple Hibiscus is placed within the broader question of the novel's representation of the Nigerian postcolony and 
the specific form of its political critique. Important here is the novel's negotiation of what Pius Adesanmi calls the "anxieties of postcolonial temporality"-specifically, the kind of relationship that is imagined between the present and the past and the extent to which the authority of the past can be acknowledged without making the "present its prisoner" ("Postcolonial" 228).

Purple Hibiscus is set in post-independence Nigeria but the action is centered in the home of Eugene Achike, a successful business entrepreneur who subjects his family to routine physical and emotional abuse. The political events that occur beyond the family scene are filtered through the limited perspective of the firstperson narrator, Kambili Achike. What emerges is a shadowy, unspecified sense of social upheaval in which political events are heard secondhand, either as news broadcasts or refracted through the lens of Papa's pious Christian-democratic viewpoint:

Of course, Papa told us, the politicians were corrupt, and the Standard had written many stories about the cabinet ministers who stashed money into foreign bank accounts, money meant for paying teachers' salaries and building roads but what we Nigerians needed was not soldiers ruling us, what we needed was a renewed democracy. (24-25)

What is depicted, albeit in elliptical form, is the stereotypical trajectory of the failed postcolonial state: the overthrow of an unwanted regime by means of a military coup, the escalation of state violence and repression and the breakdown of infrastructure leading to an entrenched totalitarianism. In this way, Nigerian history is rendered not as textured or historically specific but rather in the mode of the caricatural or symbolic.

The private, familial scene, by contrast, is described in meticulous detail by a first-person narrator whose attention to physical bodies, material objects, and inhabited space is unwavering. The particular choice of this narrative perspective not only establishes the familial space as a privileged site of historical narration, but also asserts the centrality of the body in the understanding of this history. Kambili's preoccupations with the corporeal self encompasses a fascination with the body of the tyrannical father, the body of the priest, the body of the mother, and the changes in the body wrought by anger, impotence, freedom, sexual desire, and distress. Of particular interest to the observing, adoring child is the body of the despot himself-his lips, his smile, his "face breaking open like a coconut with the brilliant white meat inside" (25). What is striking about these descriptions is the frequency with which they border on the grotesque. When enraged by the wrong-doing in his family, Kambili observes her father Eugene's "swollen" face, "oily and discolored" (252), the "pus-tipped rashes spread across every inch" (6). In the moment of his defeat, she observes his drooping, "bulldoglike cheeks" (14) and in the prelude to anticipated violence as she follows her father upstairs, she notices that "his buttocks quivered and shook like akamu, properly made akamu, jellylike" (41). In one of the passages that reveals the paradox of a loving tyrant, she longs to "touch his face, to run her hands over his rubbery cheeks" (42).

A similar fascination with the body is evident in Kambili's response to the novel's opposing figure of progressive enlightenment, Aunty Ifeoma: "Aunty Ifeoma was as tall as Papa, with a well-proportioned body. She walked fast, like 
one who knew where she was going and what she was going to do there. And she spoke the way she walked, as if to get as many words out of her mouth as she could in the shortest time" (71). Ifeoma is described as a blend of the warrior-like and maternal. A character who embodies the emancipatory potential of a syncretized culture, she is also linked with what is constructed as a heroic precolonial past: "I imagined a proud ancient forebear, walking miles to fetch water in homemade clay pots, nursing babies until they walked and talked, fighting wars with machetes sharpened on sun-warmed stone. She filled a room" (80). The portrait of physical and intellectual exuberance, consolidated in descriptions of easy laughter, open gestures, and a capacity for spirited argument and sensual expression, is explicitly contrasted with the figure of female abjection, Beatrice Achike, who walks with a limp, speaks in whispers, and echoes her husband's views. By means of this comparison, the narrative finds one of the measures of female emancipation in the strength and expressiveness of the body. What is suggested here is an understanding of idealized femininity as a condition of physical boundedness in which the privileged habitus of stillness and silence places limits on the body itself. In similar fashion, the narrative of female individual emancipation that provides the focus of this text is also articulated through body figures of various kinds: Kambili's progress is from stuttering, choking, and silence to speech, argument, questioning; from the still, closed, negated body encouraged by the church (or the nonfunctional bodies of the privileged) to a body that works, sweats, runs, laughs, desires, dances, and sings.

Central to the political concerns of the novel is the narrative of Western colonial negation, and the haunting of the colonial past, a narrative that is also told primarily in relation to the body and body effacement. At work here is not only the specific colonial project of disciplining the native body against the propensity for laziness or sexual excess, but also the foundational dualistic logic of Western philosophical discourse in which mind and body are polarized and hierarchized. In this bifurcated logic, the mind is that which must be defended against the unruly, suggestible body: the body in turn is "a brute givenness which requires overcoming, a connection with animality and nature that needs transcendence" (Grosz 3). Within the Christian tradition, as Elizabeth Grosz explains, this distinction is refigured as a division between a "God-given soul" and a "sinful carnality," a rendering of the mind/body opposition that is also "correlated to the distinction between what is immortal and what is mortal" (5).

In Purple Hibiscus, the principal figure of this profound somatophobia is Eugene Achike, product of missionary education, who takes on the burden of Judeo-Christian belief in the body as encumbrance and trap, of the body as allied to sin and Satan. The ensuing project, abetted by the Catholic priest, Father Benedict, centers on the disciplined body trained into the postures of religious observance and stilled in the habitus of contrition, obeisance, and modesty. In the world of the novel, these prohibitions are suggested in the importance of head coverings, restrictions on physical movement, prohibitions on nakedness, and the elimination of affect. In the most extreme case, evident in the spiritual habits of the character Eugene, the disciplined body of strict religious observance is contorted into the postures of the self-abnegating grotesque-the tongue extended as far as it can go as it becomes the recipient of the host, the eyes shut tight in a grimace of prayer, and the body made to occupy painful postures (knees bearing down on marble 
floors) in the conspicuous performance of piety. In these gestures, self-inflicted pain is confirmed as the sign of religious conviction.

Examples of the disciplined body described above are also shadowed by more brutal forms of punishment for the sins of the flesh. In keeping with the Christian colonial logic of the unruly body-source of sin and the site of repression-the forms of domestic discipline in the Achike household center on corporeal repression and punishment: non-performing fingers are crushed and disabled, feet and hands that "walk into sin" (194) are scalded, bodies that offer resistance are beaten, slapped, punched, kicked. The body and its frailties form the ground of the family tensions and the work of family life is to bring this body under control. Particularly egregious in this domestic system are the frailties of the female body, as morning sickness and menstrual cramps present obstacles to religious observance (Stobie, "Gendered Bodies" 315).

In the relationship of the father to the child-a relationship that also replicates that of the priest and the novitiate-the novel gives further attention to the complex nexus of suffering and redemption, pain and salvation. The Christian discourses of sin and redemption, exemplified in the suffering body of Christ, give privileged place to a view of the body as nobly and necessarily wounded in pursuit of purity, salvation, or the presence of God. The novel engages with this idea in the many sequences in which the flesh is mortified and the soul redeemed through ritual beatings: the violence against Beatrice Achike after a tentative attempt to evade Papa's authority, the family beating that ensues after Kambili breaks the Eucharist fast, and the scalding of the children's feet after cohabiting with a "heathen" are just some of the instances of family violence that are apposite here. A more benign version of the link between love and pain is indicated in the family ritual of the "love sip" in which the experience of fatherly intimacy is contingent on the burning of flesh:

Have a love sip, he would say, and Jaja would go first. Then I would hold the cup with both hands and raise it to my lips. One sip. The tea was always too hot, always burned my tongue.... But it didn't matter, because I knew that when the tea burned my tongue, it burned Papa's love into me. (8)

As has been suggested, the Christian animus against the body is overlaid with conventional colonial readings of blackness. As a mere "body-thing, that which belongs to the sphere of objects, the profane black body is denied transcendence" (Mbembe 27). As a peculiarly degraded form of the human (animalistic, irrational, hypersexual) it also requires the continual exertion of vigilance and the ritualized humiliation of the flesh. Purple Hibiscus explores the anomaly of inhabiting a black body in a Christian-Catholic context in which all the images of Christ have white hair and "wide white hands" (131) and in which even God has a British accent. In this respect, as Anthony Chennells has argued, the novel retains its allegiance to Catholicism but takes up a critique of a variant of colonial Catholicism in which God is located in Europe. Of related concern is the attention the novel gives to the phenomenological experience of race-the emergence of what Frantz Fanon describes as a "racial epidermal schema," a racialized identity scripted from without (84). In the cauldron of Western colonial-Christianity, as is powerfully suggested in the figure of Papa Eugene, the desire of the haunted mimic man is toward a perfect 
disembodiment, an invisibility in which flesh no longer signifies. Central to the colonial-missionary endeavor, the novel asserts, is not only the negation of the black body, but also the language and culture of the Igbo people. ${ }^{2}$ As Father Benedict confirms, the expulsion of the native is the necessary prerequisite to Christian spirituality. Interestingly, the version of Igbo culture rendered here, in opposition to a "pinch-nosed" whiteness (4), partakes in the conventional-stereotypical representations of African expressiveness, embodiment, and spontaneity. The novel's critique of colonial-Christian culture relies in part on a basic opposition between the notion of African exuberance and the equally stereotypical construction of whiteness as physical immobility, passivity, and quietude.

It is against the dominant Western philosophical and Christian-colonial narratives of body shame and negation that the portrait of Eugene's father, the traditionalist Papa-Nnukwu, takes on its full significance. In this sequence, Kambili is the silent, unheeded observer as her grandfather conducts his morning prayers. Significant here is the loving depiction of an ageing body, both cast into new light and familiarized through comparison to the ordinary, homely, edible, and sustaining: his skin hanging low like a "brown leather pouch" (167), his furrowed skin like mosquito netting or eggplant, his teeth like "fresh corn-kernels" (168):

When Papa-Nnukwu rose and stretched, his entire body, like the bark of a gnarled gmelina tree in our yard, captured the gold shadows from the lamp flame in its many furrows and ridges. Even the age spots that dotted his hands and legs gleamed. I did not look away, although it was sinful to look upon another person's nakedness. The rumples in Papa-Nnukwu's belly did not seem so many now, and his navel rose higher, still enclosed between folds of skin. Between his legs hung a limp cocoon that seemed smoother, free of the wrinkles that criss-crossed the rest of this body like mosquito netting. He picked up his wrapper and tied it around his body, knotting it at the waist. His nipples were like dark raisins nestled among the sparse grey tufts of hair on his chest. $\mathrm{He}$ was still smiling as I quietly turned and went back to the bedroom. (168-69)

In this portrait of a man saying his morning prayers, Adichie musters all the resources of pathos and humanitarian sentiment against the long history of black body shaming and the related body aversions of the Christian tradition. The reimagined body, pointedly rendered in unclothed form, is not only dignified in its old age, not only venerated through its connections to soil, trees, bark, and food, but also fetishized as an object of worship. In the glow of the lamp flame, the brown and wrinkled skin turns to gold and topaz. Further potential for a transgressive "body rewriting" lies in the depiction of the body as feminized and flaccid (against the conventional descriptions of phallic power) and the fact that the onlooker is a young girl (Stobie, "Gendered Bodies" 322). That the unclothed body is also engaged in an act of worship is also crucial for the narrative concerns: not only does it establish the "heathen" as a man of intense spirituality, but it also hints at the possibility of an embodied spirituality in contrast to the body-negating practices of the Christian son. As Brenda Cooper suggests, what the novel inscribes is a version of nakedness that merges with spiritual belief (120). Adding to the humanizing portrait is the construction of a spiritual practice as a sanctification rather than repudiation of family ties and as a declaration of innocence rather than a confession of guilt. 
The depiction of the abusive patriarch who controls the domestic realm through a combination of violent punishment, exacting schedules, and ritualized performance is also characterized by a persistent and untoward attention to the corporeal self. As has been suggested, these descriptions are centered on the mouth, skin, eyes, and buttocks and place emphasis on the physically repulsivethe rubbery, oily texture of his skin, the presence of pus and discoloration-and the suggestion of sexual desire (shaking, swollen, mobile flesh, red-rimmed eyes). Imagining her father's physical response to her rebellion, Kambili remarks that "his eyes would narrow, his cheeks would bulge out like unripe udala fruit, his mouth would spurt Igbo words" (209). Aspects of the grotesque are also evident in Kambili's descripion of the beating that follows: Papa swayed slightly from side to side, like a person about to fall at the feet of a charismatic pastor after the laying on of hands. Papa did not sway often. His swaying was like shaking a bottle of Coke that burst into violent foam when you opened it (209-10). What is suggested in the descriptions of the father-despot are contradictory images of Papa Eugene as both susceptible (feminized) religious convert and fleshy human body aroused by the prospect of inducing pain. The body of the father that surfaces in the family confrontation is libidinous, volatile, and irrational. The exaggerated, excessive body forms an ironic counterpoint to the affectless body of the disciplined public man.

The image of the tumescent, libidinous body in these and other passages marks a point of articulation with Mbembe's postcolonial grotesque, an image developed in tension with the Bakhtinian notion of the grotesque as corporeal parody and subversion through boundary transgression, formlessness, growth, and mutation. Mbembe proposes a shift from a reading of the grotesque and obscene as the province of ordinary people enacting modes of parody and resistance to an understanding of these modes as part of the dramatization of state power-spectacles centered on the body and its grandiloquence that facilitate the apparatus of rule. As Mbembe argues, the body and its functions (eating, defecating, desiring) have become commonplace tropes in the vernacular representation of power. By giving voice to the bodily grotesque, the subject both acknowledges the centrality of the body of the potentate in the exercise of power and understands the potential it holds for transgressive unmasking (106-07). In this latter gesture, an unseemly focus on the vulgarities of the "body of our Lord" provides one of the means whereby the fetish of postcolonial authority can be named and exposed. As Mbembe explains, the fetish, "seen for the sham it is, is made to lose its might and becomes a mere artifact" (108).

In Purple Hibiscus, the persistent attention that is given to the body of the father can be seen as partaking in this well-established tradition. As the object of the unflinching gaze of an acquiescent and adoring daughter, the exacting domestic despot is unwittingly exposed as a man of the flesh. As Cheryl Stobie has argued, the dethroning of the patriarch is clearly a central narrative trope; however, the novel's insistent inscription of the fleshy, incontinent body accomplishes a simultaneous reading of Papa Eugene as the bloated figure of the authoritarian state whose ordinariness is confirmed though a range of carnivalesque or, as Mbembe would have it, "convivial" gestures of unmasking. This reading of Papa Eugene as a postcolonial potentate (or perhaps more usefully as emblematic of a set of practices, rituals, and figures associated with Mbembe's postcolonial commandement) finds further consolidation in the descriptions of Eugene's 
public performances-his Christ-like enactment of spiritual agony, his spectacular wealth, his theatrical gestures of excessive magnanimity-and his private propensity for violence. In this sense, the text goes further than serving as a critique of authoritarianism by means of the depiction of its domestic equivalent. In the figure of Eugene, the novel offers an intimate portrait of the autocratic function itself. As in the dethroning of the father, the potential for transgression lies in the unmasking narrative gaze, in the scrutiny of the flesh. To return to Mbembe's formulation, through these and other examples of "body writing" in the text, the fetish that aspires to sacralization is repeatedly brought low. The attention given in the novel to the body of the despot (both its grotesque theatricality and the possibility of its unmasking) suggests a construction of the postcolony that has clear affiliations with Mbembe's view. This is not to install Mbembe's text as authoritative, the truth of which is confirmed by fiction, but rather to point to a shared prognosis.

Interestingly this trope of unmasking works in tension with what Cooper identifies as a characteristic gesture of "reenchantment" in Purple Hibiscus in which ordinary objects (such as a cherished painting of Papa-Nnukwu) are reanimated or fetishized as a means of reaching back into the precolonial past. What this points to is a contradictory or unstable aspect of the text in which the notion of the fetish as a form of positive reclamation vies with the more skeptical reading of the fetish as that which must always be decried.

The insistent deployment of body tropes as part of a destabilizing aesthetic links this novel with other instances of transgressive "body writing" such as are to be found in the work of Zimbabwean author Yvonne Vera and Cameroonian writer Calixthe Beyala. ${ }^{3}$ Working in tandem with this insistent body focus is a pervasive narrative structure of splicing or mirroring in which the narrative of the family and the narrative of the state are explicitly brought into connection. In these instances, repeated scenes of domestic abuse are shadowed and supplemented by descriptions of repressive or violent actions in the public sphere. As the violence in the Achike home intensifies, so the authoritarian state begins to apply its force-first, through routine inspections, roadblocks, and raids and then in the more extreme forms of beatings, public hangings, assassinations, and imprisonment. Much of the existing literature on the novel has engaged with the problem of finding the appropriate figures to describe the precise relationship between family and state as it is imagined in the novel: as a microcosm of state and church (Stobie, "Dethroning" 423), as parallelism and ironic juxtaposition (Andrade 96), and as metonym or "foil" (da Silva 455). ${ }^{4}$ If many of these critics find the social value of the text in its critique of contemporary postcolonial relations of power and the architecture of oppression, they are also careful to resist an allegorical reading of the family as a stand-in for the state. ${ }^{5}$

In similar spirit, my reading of Eugene as an emblematic figure of the authoritarian imaginary takes nothing away from the equally striking story of patriarchal abuse and a young girl's incipient disenchantment. Instead, what is asserted is a relation of reflection, refraction, and reciprocity in which the personal realm both retains its singularity and becomes a refracting mirror in which the specific qualities of state violence can be examined afresh. Central to this reciprocal structure is the trope of the bodily grotesque, a figure that both articulates the continuities between the private world of domestic violence and the public world of the postcolonial state and holds them within a single frame. What is revealed in this logic 
of mirroring are the characteristic patterns of authoritarian rule-not only the silencing of dissent and the control of persons, but, as the focus on the family scene makes clear, the intimacy of its address and its tenacious hold on consciousness. In this refracting, mutually illuminating relationship, that which pertains to the personal or familial sphere is also figured as always-already contaminated by the public authoritarian template. In this sense, what is pursued is a reading of the domestic world in Purple Hibiscus as a dramatization of the reproduction of the grotesque master code in the "remotest, tiniest corners of everyday life" (107). As an echo, reinscription, or mirroring, the violence of the domestic sphere and the violence of the state are rendered as reciprocal and mutually illuminating. In this sense, as Cooper and others have suggested, the novel's destabilizing aesthetic also extends to the conventional distinctions between the personal and the political, the private and the public.

The reading of Papa Eugene as a figure of the self-aggrandizing postcolonial commandement works in tension with the interpretation of the character as a complex psychological portrait-as a brutalized figure of colonial violence, a compromised colonial mimic man (Cooper 128; Stobie, "Dethroning" 424), or a tragic but admirable figure "seeking to do right in many spheres" (Wallace 471). What I wish to foreground instead is a marked tendency in the characterization of Eugene toward a kind of unwarranted textual excess, one that tends to exceed the bounds of psychological realism. ${ }^{6}$ This is evident not only in Eugene's superfluous characterization as a successful entrepreneur, a man of the church, a Christ-like figure, people's idol, a domestic tyrant, a defender of Western-style democracy, and, as one critic would have it, a compromised beneficiary of neocolonialism (da Silva 456), but also in the "thickness" of the novel's descriptions. These competing layers of signification, I suggest, encourage a reading of the character not only as complex psychological portrait, but as a multivalent and unstable textual signifier, only one of the meanings of which is the decadent body of the autocrat. Once released from the orders of realism, Papa's significance knows no bounds.

A further possibility that presents itself to this perspective is a reading of Eugene as an atavistic figure of the colonial potentate whose deployment of corrective violence is sanctioned by the church. In the disciplining practices carried out in his home, the aversion to the body, and the punishment of sin, Eugene continues the colonial project of civility, the enforcement of decorum, and the grooming of the native. Like the colonial potentate, too, Eugene conceives of his violent acts in terms of the burden of enlightenment. This paradoxical textual doubling-as colonial sovereign and postcolonial autocrat-links to what has already been identified as a prominent narrative structure, namely the assertion of reciprocity. In this case, what is presented is a structure of brutality in which the violence of the colonial mission, the violence of patriarchy, and the violence of postcolonial regimes are explicitly linked. These continuities are reinforced by the novel's employment of the trope of burning flesh: the private scalding of feet and hands as church- and family-sanctioned punishment is echoed in the public sphere in the image of acid poured over the body of the political dissident.

What is particularly unexpected in this text is the linking of the traces of colonial and postcolonial corruption with the values of Western democracy. Accordingly, much of the existing criticism seeks ways to reconcile the conundrum of Eugene Achike's ambiguous status as an exemplar of liberal-democratic freedoms 
and a figure of brutal, authoritarian violence. As hinted at above, a characteristic response is to interpret this paradox in personal-psychological terms as a failure to translate the values of democracy into the private sphere. A further possibility lies in the aforementioned figure of reciprocity, one in which the discourses of democracy and tyranny are linked rather than polarized. The slippage between the conventionally differentiated roles of democrat and tyrant is perhaps most sharply indicated in the passage in which Ade Coker, the editor of the prodemocracy newspaper the Standard (a newspaper that is also funded by Eugene) remarks on the impeccable behavior of Eugene's children. Eugene's reply exemplifies his posture of self-righteous complacency:

\footnotetext{
"They are not like those loud children people are raising these days, with no home training and no fear of God," Papa said, and I was certain that it was pride that stretched Papa's lips and lightened his eyes.

"Imagine what the Standard would be if we were all quiet."

It was a joke. Ade Coker was laughing; so was his wife, Yewande. But Papa did not laugh. Jaja and I turned and went upstairs, silently. (58)
}

By hinting at the discrepancy between an outspoken newspaper and the compliance and silence of the family home, Ade Coker reveals the basic contradiction between the value of civilized decorum as part of the colonial-enlightenment project, on the one hand, and the humanist values of personal liberty and freedom of expression, on the other. By making an unwitting connection between government censorship and the silence of the Achike home, Coker also exposes the continuum of tyranny in the private and public realms. In this light, I pursue a reading of Eugene's domestic tyranny as of a piece with, rather than differentiated from, his Western-derived democratic beliefs. To consolidate this argument, I make recourse to Gayatri Spivak's discussion of the categorical imperative by means of which the colonized subject_Europe's "not-yet-human other" (247) —is made human by violent means. In this sense, Papa Eugene as the "object of what might be termed the terrorism of the categorical imperative" (248) subjects his children to a similar regime as part of the project of Western enlightenment. What is suggested here is not the paradox of Western enlightenment and tyranny but their reciprocal relationship. In this reading, Eugene emerges as the conflictual figure of this unresolved tension.

Beyond this particular instance, the novel's propensity toward signifying excess makes possible a chain of associations in which the body of the father, the body of the priest, the body of Christ, the figure of the despot, and the bearer of Western enlightenment values become interchangeable, conceivable as part of a single system. In this way, the novel asserts a series of untoward connections across conventionally bounded conditions-colonial religious authority, autocratic governance, the patriarchal order, and Western rationality. As in the imagined relationship between family and the state, the logic of mirroring and refraction serves as a means of illuminating connections. Particularly striking are the transgressive possibilities encouraged by this nexus of signs, a narrative structure that bears a close resemblance to the aforementioned trope of reciprocal unmasking or desacralization in which spirit is made flesh, god is made human, and that which is transcendent is rematerialized. 
Of particular interest in the novel's use of this reciprocal structure is the treatment of temporality not as a linear chronicle but as merging and entanglement, one that asserts the simultaneous existence of the present and the past. As such, the novel can be said to embrace a reading of the authoritarian postcolonial imaginary as the inheritance of colonialism, of an understanding of the past and present as overlapping and intricately entangled. In Mbembe's terms, what is suggested are the ways in which the institutions of colonial autocracy provide the "cement of [contemporary] postcolonial African regimes" (32). In this sense, I privilege a reading of the novel not only as a meditation on postcolonial relations of subjection and abuse, but also as a reflection on the legacy of colonial violence and the ongoing presence of the past. ${ }^{8}$

Purple Hibiscus is noteworthy for the attention it gives to the body and the various cultural, social, and political meanings with which it is inscribed. Taking shape as a kind of narrative of the body itself, it moves against a Western condescension for the body as trivial or aligned with the "feminine" by elucidating the significance of the body and bodies in history. ${ }^{9}$ This history is inscribed in a number of ways: in the story of the Achike family - and the refracted story of the nation-the body is posited as a principal site of physical and discursive violence, a compelling target of the various ideological projects of colonial-Christianity, patriarchy, and absolutism. In the novel's narrative of female individualist emancipation, the centrality of the body is confirmed in the emancipatory teleology of burgeoning physical and vocal expression. In a similar fashion, the history of colonial racism and the accompanying negation of the black body are countered by a radical revisioning of "blackness" that bears some resemblance to the work of Yoruba photographer Rotimi Fani-Kayode. In keeping with a long tradition of corporeal parody, the novel also offers a reading of the bodies of the powerful as a site of transgressive unmasking. As I have suggested, these concerns form the key components of a form of "body writing" that gestures toward the destabilizing or subversive.

In the portrait of the larger than life Papa Eugene, the novel reiterates and reifies the pessimistic, satirical view of the fleshy postcolonial demagogue and his distinctive regime of violence, thus confirming Mbembe's construction of the postcolony as a site of cruelty and excess. As in Mbembe too, the text calls attention to the corporeal manifestations of power and of the body as a site of satirical unmasking in which the pretentions of the potentate can be revealed. In Purple Hibiscus, however, the gestures of transgression do not take the form of the publicly raucous, ribald, or comical. Instead, the quiet scrutiny of the body performs an act of desacrilization in which the fetish is stripped of its significance and returned to the mundane. In a similar fashion, a repeated structure of mirroring and refraction facilitates critique through the tracing of unexpected connections. What the novel appears to confirm is that modes of everyday political action in the postcolony are limited to the symbolic realm, what Cooper describes in a reference to Moses Isegawa's Abyssinian Chronicles (2000) as "the capacity to drain the excess and to strip the metaphor back down to the everyday solid object that it is" (92). In Purple Hibiscus, a comparable verdict on the possibilities of direct political resistance-the political force of bodies in the street-is also suggested in the ease with which bodies are disciplined into obedience through the violence of the state. Performing a similar function in the text is a fleeting description of a 
communal gathering - the waving of green leaves in celebration of the military coup - in which the exercise of public political engagement is reduced to the formulaic, unthinking, and grotesque. In the particular orders of valuing inscribed in the novel, what appears to be given greater prominence is the form of political engagement through analysis and critique.

In the figure of Papa Eugene, the novel offers a critique of postcolonial tyranny, of the glorious leader as bloated dictator in the manner of Ngũgĩ wa Thiongo's Ruler of the fictional state of Aburĩria in Wizard of the Crow (2006). ${ }^{10}$ Through the multiple configurations of Eugene as a liberal democrat and a man of the church, however, the novel also delineates other lines of signification that complicate the satirical portrait. As a figure of the colonial potentate, Eugene is historicized in relation to the colonial missionary project. As an advocate of democracy and a successful businessman, the character of Eugene also intimates that the forms of the democratic and the forms of the violent are not always easily distinguished. In this way, the novel takes issue with complacent Western constructions of Africa as the predictable and monotonous signifier of political and economic corruption: a continent that can be dismissed with the phrase, "all that corruption, all that heat" (Adichie 300). If Purple Hibiscus discloses "the continued presence of the script of colonialism" (Adesanmi, "Of Postcolonial" 238), it avoids the dangers of privileging the ontology of the past by exploring the banality of contemporary power, both in Nigeria and elsewhere.

\section{NOTES}

1. Particularly important here are contributions by Pius Adesanmi ("Europhonism," "Of Postcolonial"), Flora Veit-Wild, Heather Hewett, and a collection of essays edited by Flora Veit-Wild, and Dirk Naguchewski. Critics who have given specific attention to the significance of the body in Adichie's work include Stobie ("Gendered Bodies") and da Silva.

2. For a detailed discussion of the politics of language in the context of missionary Catholicism, see Mabura.

3. For more detailed discussion of these writers in relation to the body, see Adesanmi ("Europhonism") and Weit-Vild.

4. Herbert Ekwe-Ekwe prefers a more direct relation: "The retrograde religiosity and brutishness of Eugene can easily be codified as that working ideology of heightened self-conceit and repression, if ever there was one, which links the regimes of the five notorious Nigerian dictators of the era: Generals Buhari, Babangida, Abacha, Abubakar and Obasanjo" (118).

5. See, for example, Cooper; Ouma; and Andrade.

6. Da Silva makes a similar point when he suggests that "Eugene's character acquires a political meaning that is absolutely central to his familial function and overwrites it" (457).

7. See, for example, Hewett; Cooper; Chennells; Stobie; and Andrade.

8. It is for this reason that I would take issue with the argument made by da Silva that the novel's critical focus is directed not so much at the colonial past as at "the contempt for the rights of citizens demonstrated by so many government structures in the present" (466).

9. For a range of feminist approaches to the body, see Spelman; Bordo; Grosz; Price; and Shidrick and Shiebinger. 
10. To this could be added Dambudzo Marachera's Black Sunlight (1980) and Sony Labou Tansi's L'Etat honteux (1981), among others. See Weit-Vild.

\section{WORKS CITED}

Adesanmi, Pius. "Europhonism, Universities, and Other Stories: How Not to Speak for the Future of African Literatures." Palavers of African Literature: Essays in Honor of Bernth Lindfors. Vol. 1. Ed. Toyin Falola and Barbara Harlow. Trenton; Asmara: Africa World Press, 2002. 105-36. Print.

"Of Postcolonial Entanglement and Durée: Reflections on the Francophone Novel." Comparative Literature 56.3 (2004): 227-42. Print.

Adichie, Chimamanda Ngozi. Purple Hibiscus. 2003. London: Harper Perennial, 2005. Print.

Andrade, Susan. "Adichie's Genealogies: National and Feminine Novels." Research in African Literatures 42.2 (2011): 91-101. Print.

Bakhtin, Mikhail. Rabelais and His World. Trans. Hélène Iswolsky. Bloomington: Indiana UP, 1984. Print.

Bordo, Susan. Unbearable Weight: Feminism, Western Culture and the Body. Berkeley: U of California P, 1993. Print.

Chennells, Anthony. "Inculturated Catholicisms in Chimamanda Adichie's Purple Hibiscus." English Academy Review 26.1 (2009): 15-26. Print.

Cooper, Brenda. A New Generation of African Writers: Migration, Material Culture and Language. London: James Currey, 2008. Print.

da Silva, Tony Simoes. "Embodied Genealogies and Gendered Violence in Chimamanda Ngozi Adichie's Writing." Atrican Identities 10.4 (2012): 455-70. Print.

Ekwe-Ekwe, Herbert. Readings from Reading: Politics, Genocide, Literature. Dakar; Reading: Africa Renaissance, 2011. Print.

Fanon, Frantz. Black Skin, White Masks. 1952. London: Pluto, 1986. Print.

Foucault, Michel. Discipline and Punish: The Birth of the Prison. 1977. London: Penguin, 1987. Print.

Grosz, Elizabeth A. Volatile Bodies: Towards a Corporeal Feminism. Bloomington: Indiana UP, 1984. Print.

Hewett, Heather. "Coming of Age: Chimamanda Ngozi Adichie and the Voice of the Third Generation." English in Africa 32.1 (2005): 73-97. Print.

Labou Tansi, Sony. L'Etat honteux. Paris: Éditions du Seuil, 1981. Print.

Ngũgĩ waThiong'o. Wizard of the Crow. New York: Anchor, 2006. Print.

Mabura, Lily. "Breaking Gods: An African Postcolonial Gothic Reading of Chimamanda Ngozi Adichie's Purple Hibiscus and Half of a Yellow Sun." Research in Atrican Literatures 39.1 (2008): 203-22. Print.

Marachera, Dambudzo. Black Sunlight. London: Heinemann, 1980. Print.

Mbembe, Achille. On the Postcolony. Berkeley: U of California P, 2001. Print.

Ouma, Christopher Ernest Werimo. "Journeying out of Silenced Familial Spaces in Chimamanda Ngozi Adichie's Purple Hibiscus." MA thesis. University of the Witwatersrand, 2009. Print.

Price, Janet, and Margrit Shildrick, eds. Feminist Theory and the Body: A Reader. New York: Routledge, 1999. Print.

Schiebinger, Londa, ed. Feminism and the Body. Oxford: Oxford UP, 2000. Print. 
Spelman, Elizabeth V. "Woman as Body: Ancient and Contemporary Views." Feminist Studies 8.1 (1982): 109-31. Print.

Spivak, Gayatri Chakravorty. "Three Women's Texts and a Critique of Imperialism." Critical Inquiry 12.1 (1985): 243-61. Print.

Stobie, Cheryl. "Dethroning the Infallible Father: Religion, Patriarchy and Politics in Chimamanda Ngozi Adichie's Purple Hibiscus." Literature \& Theology 24.4 (2010): 421-35. Print.

. "Gendered Bodies in Chimamanda Ngozi Adichie's Purple Hibiscus." Literature for Our Times: Postcolonial Studies in the Twenty-First Century. Ed. Bill Ashcroft, Ranjini Mendis, Arun Mukherjee, and Julie McGonegal. Amsterdam; Atlanta: Rodopi, 2012. 325-44. Print.

Wallace, Cynthia R. “Chimamanda Ngozi Adichie's Purple Hibiscus and the Paradoxes of Postcolonial Redemption." Christianity and Literature 16.31 (2012): 465-83. Print.

Veit-Wild Flora. "The Grotesque Body of the Postcolony: Sony Labou Tansi and Dambudzo Marechera." Revue de littérature comparée 2.314 (2005): 227-39. Web. 15 Dec. 2015.

Weit-Vild, Flora, and Dirk Naguchewski, ed. Bodies, Sexuality and Gender: Versions and Subversions in African Literature. Amsterdam; New York: Rodopi, 2005. Print. 